\title{
Effects of Fertilizer Type and Rate on the Quality and Nutrient Content of Four Species of Trees Growing in Sandy South Florida Soils
}

\author{
Timothy K. Broschat ${ }^{1}$
}

AdDITIONAL INDEX WORDs. Quercus virginiana, Swietenia mabagoni, Bucida buceras, Calophyllum brasiliense, live oak, west indian mahogany, black olive, beautyleaf, principal component analysis

SUMmARY. Broadleaf ornamental trees are known to vary widely in their responses to fertilization, depending on the species and soil and other environmental factors. Thus, it is important to study the responses of a wide range of tree species to fertilization, especially on nutrient-poor soils. Four species of temperate to tropical trees, live oak (Quercus virginiana), west indian mahogany (Swietenia mabagoni), black olive (Bucida buceras 'Shady Lady'), and beautyleaf (Calophyllum brasiliense), planted into a sandy native soil in south Florida were fertilized with a $24 \mathrm{~N}-0 \mathrm{P}-9.3 \mathrm{~K}$ turf fertilizer or an $8 \mathrm{~N}-0 \mathrm{P}-10 \mathrm{~K}-4 \mathrm{Mg}$ plus micronutrients palm fertilizer at rates of 10 or $20 \mathrm{~g}$ of nitrogen per tree four times per year. Tree height, width, caliper, and nutrient deficiency rating scores for nitrogen, potassium, and magnesium were determined at 1 year after planting (establishment period) and at 3 years after planting (maintenance phase). Data from these measured variables were subjected to principal component analysis to obtain a single measure of overall quality, namely, the scores for each tree on the first principal component. West Indian mahogany showed no response to fertilization during or following establishment. Either fertilizer type or rate improved live oak, black olive, and beautyleaf quality over that of unfertilized controls during both establishment and maintenance phases, but the high rate of the palm fertilizer was superior to either rate of the turf fertilizer for beautyleaf both during establishment and afterward. Leaf nutrient concentrations generally were poorly correlated with overall tree quality, but manganese concentrations differed significantly among treatments for all four species. Based on these results, fertilization of West Indian mahogany is not recommended, but live oak, black olive, and beautyleaf will benefit from fertilizer applied at the time of planting and after establishment.

$\mathrm{T}$ The response to fertilization of newly planted trees, as well as established trees, appears to vary greatly depending on time since transplanting, species, soil type, climate, method of application, and type of fertilizer (Struve, 2002). Fertilizer recommendations for deciduous trees growing in loam or clay soils in temperate climates would not be expected to be appropriate for evergreen species growing in sandy soils in subtropical climates such as that of peninsular Florida. Relatively little research has been published on fertilizer requirements of trees in sandy soils of Florida

Fort Lauderdale Research and Education Center, University of Florida, 3205 College Avenue, Davie, FL 33314

This research was supported by the Florida Agricultural Experiment Station and by the USDA National Institute of Food and Agriculture Hatch project FLTFTL-004945.

I thank Susan Thor and Andy Fu for their assistance in this study.

${ }^{1}$ Corresponding author. E-mail: tkbr@ufl.edu.

doi: 10.21273/HORTTECH03864-17 and much of that has used chinese hibiscus (Hibiscus rosa-sinensis), a species that may be atypical for tropical and subtropical trees because of its high nitrogen $(\mathrm{N})$ requirements (Broschat and Moore, 2010; Gilman, 1987, 1988).

Fertilizer requirements for trees during the first year after transplanting may be different from that of established trees. Gilman and Yeager (1990) did not notice significant differences in growth between fertilized and unfertilized laurel oak (Quercus laurifolia) during the short 17- month duration of their study. Gilman et al. (2000) also did not observe differences among treatments in the growth of southern magnolia (Magnolia grandiflora) during the first year after planting, but treatment differences were significant after 3 and 4 years. On the other hand, fertilized live oak (Quercus virginiana) were larger than unfertilized trees during their first year (Gilman et al., 2000).

Most fertilizer studies on trees have concentrated on $\mathrm{N}$ requirements, yet in Florida landscapes $\mathrm{N}$ deficiency symptoms are seldom observed. Magnesium deficiency is fairly common on Florida trees (Dickey, 1977), but it is not known if routine application of magnesium $(\mathrm{Mg})$ or micronutrient-containing fertilizers would result in superior growth or visual quality. Gilman et al. (2000) found no response to applied phosphorus $(\mathrm{P})$ or potassium $(\mathrm{K})$ in live oak, but this species rarely exhibits deficiencies of any nutrient element in the landscape.

Because responses to fertilization appear to vary greatly among species and in different soils and environments, it is important to study the growth responses of individual species, especially on nutrient-poor soils. The purpose of this study was to determine how four trees commonly grown in south Florida respond to two commercially available types of fertilizer, a typical turf fertilizer that contains no $\mathrm{Mg}$ or water-soluble micronutrients and a palm fertilizer that contains large amounts of $\mathrm{K}, \mathrm{Mg}$, and soluble micronutrients, and to determine if fertilizer rate is important, both during and after establishment.

\section{Materials and methods}

Trees grown in 10-L polypropylene containers were transplanted into a Margate fine sand soil (siliceous, hyperthermic Mollic Psammaquent, $\mathrm{pH}$ 5.2) in Davie, FL, on 5 June

\begin{tabular}{llll}
\hline $\begin{array}{l}\text { Units } \\
\text { To convert U.S. to SI, } \\
\text { multiply by }\end{array}$ & U.S. unit & SI unit & $\begin{array}{l}\text { To convert SI to U.S., } \\
\text { multiply by }\end{array}$ \\
\hline 0.3048 & $\mathrm{ft}$ & $\mathrm{m}$ & 3.2808 \\
0.0929 & $\mathrm{ft}^{2}$ & $\mathrm{~m}^{2}$ & 10.7639 \\
3.7854 & $\mathrm{gal}$ & $\mathrm{L}$ & 0.2642 \\
2.54 & inch $(\mathrm{es})$ & $\mathrm{cm}$ & 0.3937 \\
4.8824 & $\mathrm{lb} / \mathrm{l}, 000 \mathrm{ft}^{2}$ & $\mathrm{~g} \cdot \mathrm{m}^{-2}$ & 0.2048 \\
10 & $\mathrm{meq} / 100 \mathrm{~g}$ & $\mathrm{mmol} \cdot \mathrm{kg}^{-1}$ & 0.1 \\
28.3495 & $\mathrm{oz}$ & $\mathrm{g}$ & 0.0353 \\
1 & $\mathrm{ppm}$ & $\mu \mathrm{g} \cdot \mathrm{g}^{-1}$ & 1
\end{tabular}


2012. Soil samples $(n=6)$ taken at the time of planting showed a mean organic matter content of $5.0 \%$, cation exchange capacity of $7.5 \mathrm{meq} / 100 \mathrm{~g}$, available phosphorus $\mathrm{P}(\mathrm{Pl})$ of 9.0 ppm, K averaged 16.3 ppm, Mg 35.8 $\mathrm{ppm}$, and calcium (Ca) $2308 \mathrm{ppm}$. A randomized complete block design was used with trees spaced $3 \mathrm{~m}$ apart in linear blocks separated from other blocks by a distance of $5 \mathrm{~m}$ in all directions. There were eight replicate blocks containing one plant of each species for each treatment. Species used were live oak, west indian mahogany, black olive, and beautyleaf, four of the most common large tree species planted in south Florida.

Fertilizers were applied at the time of transplanting and every 3 months thereafter for 3 years. Treatments included 1) no fertilizer (CONTROL), 2) a $24 \mathrm{~N}-0 \mathrm{P}-9.3 \mathrm{~K}$ turf fertilizer [24-0-11 (Lesco, Cleveland, $\mathrm{OH})]$ applied at a rate of $41.7 \mathrm{~g} /$ tree, 3 ) the same turf fertilizer applied at $83.4 \mathrm{~g} /$ tree, 3 ) a $8 \mathrm{~N}-0 \mathrm{P}-$ $10 \mathrm{~K}-4 \mathrm{Mg}$ plus micronutrients palm fertilizer [8-0-12 (Nurserymen's Sure Gro, Vero Beach, FL)] applied at $125 \mathrm{~g} /$ tree, and 4) the same palm fertilizer applied at $250 \mathrm{~g} /$ tree. The turf and palm fertilizer application rates provided equivalent amounts of $\mathrm{N}$ equal to 10 and $20 \mathrm{~g} /$ tree of $\mathrm{N}$ per application for the low and high rates, respectively. Fifty percent of the $\mathrm{N}$ in the turf fertilizer was in controlledrelease (3-month release) form (polymercoated urea) with the remainder being water-soluble (urea). The turf fertilizer contained water-soluble $\mathrm{K}$ from potassium chloride and $2 \%$ iron $(\mathrm{Fe})$ and $1 \%$ manganese $(\mathrm{Mn})$ in insoluble sucrate forms. All of the N, $\mathrm{K}$, and $\mathrm{Mg}$ in the palm fertilizer were controlled release (3-month release; polymer-coated urea, polymer and sulfur-coated potassium sulfate, and kieserite) and $1.25 \% \mathrm{Mn}, 1.17 \% \mathrm{Fe}$, $0.15 \%$ zinc $(\mathrm{Zn}), 0.06 \%$ copper $(\mathrm{Cu})$, and $0.6 \%$ boron (B) were provided by manganese sulfate, iron sulfate, iron ethylenediaminetetraacetate (EDTA), iron diethylenetriaminepentaacetate (DTPA), zinc sulfate, copper sulfate, and sodium borate. All fertilizers were applied by broadcasting uniformly over a $1-\mathrm{m}^{2}$ area surrounding each tree. After l year, it became apparent that $\mathrm{P}$ deficiency was limiting growth and resulting in visible $\mathrm{P}$ deficiency symptoms in the black olive trees so all trees of this species, including controls, received $40 \mathrm{~g}$ of triple superphosphate $(0 \mathrm{~N}-$ $18.8 \mathrm{P}-0 \mathrm{~K}$ ) fertilizer [0-43-0 (Helena Chemical, Ft. Pierce, FL)] every 3 months. In Jan. 2014 this amount was increased to $160 \mathrm{~g} /$ tree spread over a $4-\mathrm{m}^{2}$ area surrounding each tree. This $\mathrm{P}$ fertilization was done to prevent the effects of $\mathrm{P}$ deficiency from confounding tree responses to the fertilizer treatments, none of which contained any $\mathrm{P}$.

All trees received $\approx 2 \mathrm{~cm}$ of water from overhead irrigation three times per week during the first 6 months and twice per week thereafter. An area of $\approx 1 \mathrm{~m}^{2}$ around all trees was kept weed-free with glyphosate. Minimal pruning was periodically done to establish strong central leaders and good branch structure. All trees were measured at the time of transplanting and every year thereafter for total height, width in two opposite directions (parallel and perpendicular to rows), and stem caliper at $30 \mathrm{~cm}$ above the ground. The two width measurements were averaged to obtain a single value. Growth was calculated as the height at the end of 1 year (establishment period) minus initial height. Growth during the maintenance phase was calculated as the final height after 3 years minus the height at the end of the establishment phase. At the time that measurements were taken, all trees were subjectively rated for severity of $\mathrm{N}, \mathrm{K}$, and $\mathrm{Mg}$, deficiencies on a scale of 1 to 5 with a rating of 1 being severe and 5 being completely free of deficiency symptoms for that element.

Because plant size variables, such as height, width, and stem caliper, are typically highly intercorrelated, principal component analysis was performed on the data to reduce the seven original variables to a single index of overall quality, namely, the scores on the first principal component (Broschat, 1979). All quality data were standardized to a mean of 0 and a SD of 1 to eliminate the effects of differences in scale among the original variables using PROC STANDARD (SAS version 9.4; SAS Institute, Cary, NC). Principal component analysis was done using PROC PRINCOMP with scoring by PROC SCORE. In this analysis, the first principal component typically contains high positive correlations for most or all of the original variables with the first principal component, making it a useful index of overall quality. These scores for each tree on the first principal component were further subjected to analysis of variance (PROC GLM) with mean separation by the Waller-Duncan k-ratio method $(P=$ $0.05)$ to determine treatment effects.

At the end of the experiment ( 12 Dec. 2015), leaf samples consisting of the youngest fully expanded leaves on each shoot were collected from each tree for nutrient analysis. Leaf samples were dried, ground, and digested using a modified Kjeldahl procedure (Hach et al., 1987), and they were analyzed for $\mathrm{N}$ using an autoanalyzer (Seal Analytical, Mequon, WI), P by the ascorbic acid method (Kuo, 1996), and $\mathrm{K}, \mathrm{Mg}, \mathrm{Fe}$, and $\mathrm{Mn}$ by atomic absorption spectroscopy (Perkin-Elmer, Waltham, MA). Leaf nutrient concentration data for each element were analyzed using analysis of variance with mean separations by the Waller-Duncan k-ratio method as used for plant quality data. Pearson correlation coefficients were calculated for all tree quality and leaf nutrient concentration variables using PROC CORR.

\section{Results and discussion}

A summary of the principal component analyses showed that most quality variables had high positive correlations with the first principal component ( $\mathrm{PCl})$, which typically accounted for about half or more of the variation included in the original seven variables (Table 1 ). For live oak, there were no visible symptoms of $\mathrm{N}$, $\mathrm{K}$, or $\mathrm{Mg}$ deficiencies at the end of the establishment period and thus these variables did not contribute to the overall quality scores. However, all of the other variables showed relatively high positive correlations with PCl making it a good index of overall quality in this species.

In mahogany, during establishment, all of the plant size variables plus $\mathrm{K}$ deficiency rating had high positive correlations with $\mathrm{PCl}$ (Table $\mathrm{l}$ ). Nitrogen deficiency rating had a lower negative correlation with $\mathrm{PCl}$, but the other nutrient deficiency ratings contributed little to the variability on PCl. At the end of the experiment, all of the plant size 
variables plus $\mathrm{K}$ and $\mathrm{Mg}$ deficiency ratings had positive correlations with $\mathrm{PCl}$, but other nutrient deficiencies were not present and thus made no contribution to the total variation on PCl.

For black olive during establishment, all of the size variables plus $\mathrm{N}$ rating had high positive correlations with $\mathrm{PCl}$ while $\mathrm{Mg}$ deficiency rating had a lower negative correlation with PCl (Table 1 ). At the end of the experiment, all of the plant size and deficiency ratings except $\mathrm{Mg}$ rating had high positive correlations with $\mathrm{PCl}$, making this variable a good index of overall plant quality.

In beautyleaf during establishment, no $\mathrm{N}$ deficiency was observed but all other size and quality variables were highly positively correlated with PCl (Table 1). At the end of the experiment, only the size variables and $\mathrm{Mg}$ rating had significant correlations with $\mathrm{PCl}$.

During the establishment period, all fertilizer treatments had higher quality than the unfertilized control plants for live oak, black olive, and beautyleaf, but differences among treatment means were not statistically significant for mahogany (Table 2). Gilman et al. (2000) also found that fertilized live oak was larger than unfertilized trees during their first year, but this was not the case with southern magnolia or laurel oak (Gilman and Yeager, 1990). As in this study, Gilman et al. (2000) found no effect of $\mathrm{N}: \mathrm{K}$ ratio on live oak growth. In the case of beautyleaf, the trees fertilized with the high rate of 8-0-12 had higher quality than those receiving either of the turf fertilizer treatments. Magnesium appeared to be an important element for this species, and the lack of $\mathrm{Mg}$ in the turf fertilizer was reflected in the reduced quality of trees receiving this fertilizer. Fertilizers containing $\mathrm{K}$ and urea or ammonium $\mathrm{N}$ sources can reduce $\mathrm{Mg}$ uptake by plants (Barker and Pilbeam, 2007; Scagel et al., 2008).

Established mahogany did not respond to fertilization (Table 2). However, live oak receiving any fertilizer had higher overall quality than unfertilized trees. Gilman et al. (2000) similarly found that fertilized established live oak were larger than unfertilized trees. Likewise, any fertilizer was better than none in established black olive trees, but trees receiving the high rate of 8-0-12 had higher quality than those receiving the same product at the lower rate. In established beautyleaf, any fertilizer was better than none, but trees receiving the high rate of $8-0-12$ also had higher quality than those receiving either rate of 24-0-11.

Live oak showed no differences in leaf $\mathrm{N}, \mathrm{P}, \mathrm{K}$, or Fe concentrations among treatments, but oaks receiving the low or high rates of $8-0-12$ contained more $\mathrm{Mg}$ than unfertilized trees or those receiving turf fertilizer (Table 3 ). This was expected because the palm fertilizer contains $4 \% \mathrm{Mg}$ compared with no $\mathrm{Mg}$ in the turf fertilizer. Oaks receiving either rate of the palm fertilizer also contained more Mn than control or trees receiving the low rate of turf fertilizer. Trees receiving the high rate of $8-0$ 12 also contained more $\mathrm{Mn}$ than all other treatments. Although sufficiency values have not been published

Table 1. Correlations of original tree quality variables with the first principal component for four species of trees fertilized with two rates of a $24 \mathrm{~N}-0 \mathrm{P}-9.3 \mathrm{~K}$ turf fertilizer and an $8 \mathrm{~N}-0 \mathrm{P}-10 \mathrm{~K}-4 \mathrm{Mg}$ plus micronutrients palm fertilizer during and after establishment in south Florida.

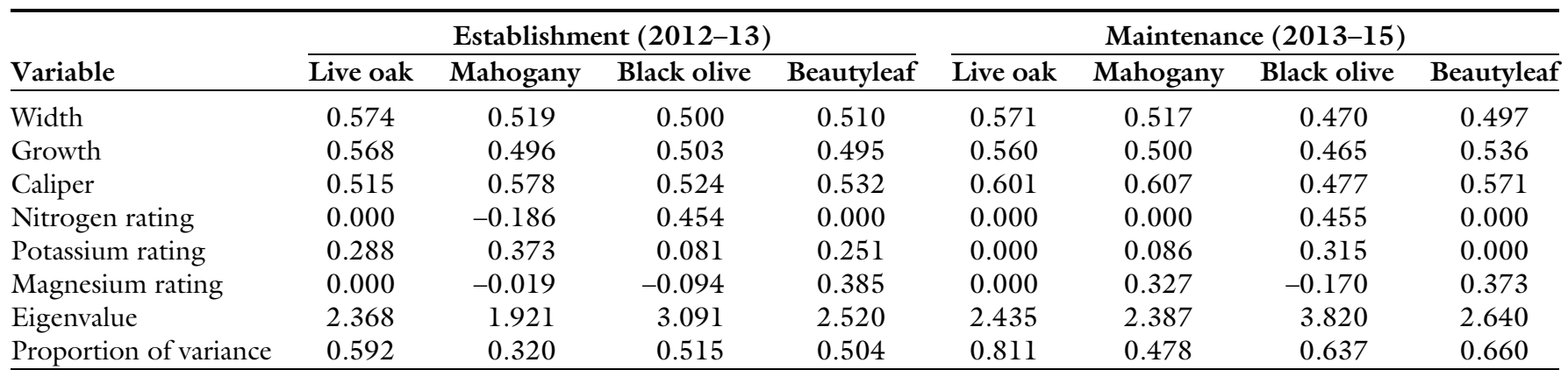

Table 2. Effects of fertilizer type and rate on overall quality (plant scores on the first principal component) of live oak, west indian mahogany, black olive, and beautyleaf during establishment and maintenance phases when fertilized with two rates of a turf fertilizer $(24-0-11)$ and a palm fertilizer $(8-0-12)$ in south Florida $(n=8)$.

\begin{tabular}{|c|c|c|c|c|c|c|c|c|c|}
\hline \multirow[b]{2}{*}{ Fertilizer $^{\mathrm{z}}$} & \multicolumn{5}{|c|}{ Establishment (2012-13) } & \multicolumn{4}{|c|}{ Maintenance (2013-15) } \\
\hline & Rate $\left(\mathrm{g} \cdot \mathrm{m}^{-2}\right)^{\mathrm{y}}$ & Live oak & Mahogany & Black olive & Beautyleaf & Live oak & Mahogany & Black olive & Beautyleaf \\
\hline Control & None & $30.6 b^{x}$ & 45.2 & $8.1 \mathrm{~b}$ & $10.4 \mathrm{c}$ & $94.1 \mathrm{~b}$ & 150.9 & $40.8 \mathrm{c}$ & $119.5 \mathrm{c}$ \\
\hline $24-0-11$ & 83.4 & $82.0 \mathrm{a}$ & 78.9 & 56.9 a & $42.3 \mathrm{~b}$ & $162.2 \mathrm{a}$ & 177.4 & $166.8 \mathrm{ab}$ & $172.0 \mathrm{~b}$ \\
\hline $8-0-12$ & 125.0 & $73.4 \mathrm{a}$ & 63.5 & $37.4 \mathrm{a}$ & $49.2 \mathrm{ab}$ & $177.4 \mathrm{ab}$ & 166.9 & $123.4 \mathrm{~b}$ & $182.2 \mathrm{ab}$ \\
\hline $8-0-12$ & 250.0 & $76.5 \mathrm{a}$ & 63.4 & $59.4 \mathrm{a}$ & $57.5 \mathrm{a}$ & $179.3 \mathrm{a}$ & 171.4 & $177.5 \mathrm{a}$ & $218.1 \mathrm{a}$ \\
\hline
\end{tabular}

${ }^{\mathrm{z}} 24-0-11$ [24N-0P-9.2K contains mostly water-soluble nitrogen $(\mathrm{N})$ and potassium $(\mathrm{K})$ plus insoluble iron $(\mathrm{Fe})$ and manganese $(\mathrm{Mn})$, but no magnesium $\left.(\mathrm{Mg})\right] ; 8-0-12$ $(8 \mathrm{~N}-0 \mathrm{P}-10 \mathrm{~K}-4 \mathrm{Mg}$ contains controlled-release $\mathrm{N}, \mathrm{K}$, and $\mathrm{Mg}$ plus water-soluble micronutrients).

${ }^{\mathrm{y}} 1 \mathrm{~g} \cdot \mathrm{m}^{-2}=0.2048 \mathrm{lb} / \mathrm{l}, 000 \mathrm{ft}^{2}$.

${ }^{\mathrm{x}}$ Mean separation by the Waller-Duncan k-ratio method $(k=100)$.

wonsignificant at $P>0.05$. 
Table 3. Effects of fertilizer treatment on leaf nutrient concentrations of live oak, west indian mahogany, black olive, and beautyleaf when fertilized with two rates of a turf fertilizer (24-0-11) and a palm fertilizer $(8-0-12)$ in south Florida $(n=8)$.

\begin{tabular}{|c|c|c|c|c|c|c|c|}
\hline$\underline{\text { Fertilizer }}$ & Rate $\left(\mathrm{g} \cdot \mathrm{m}^{-2}\right)$ & $\mathbf{N}(\%)$ & $\mathbf{P}(\%)$ & $\frac{\text { Live oak }}{\mathrm{K}(\%)}$ & $\operatorname{Mg}(\%)$ & $\mathrm{Fe}(\mathrm{ppm})^{\mathrm{y}}$ & $\operatorname{Mn}(\mathrm{ppm})$ \\
\hline Control & None & 1.62 & 0.074 & 0.5600 & $0.165 \mathrm{~b}$ & 13.82 & $29.10 \mathrm{c}$ \\
\hline $24-0-11$ & 83.4 & 1.59 & 0.063 & 0.5420 & $0.169 \mathrm{~b}$ & 22.93 & $55.35 \mathrm{bc}$ \\
\hline $8-0-12$ & 125.0 & 1.56 & 0.061 & 0.5530 & $0.201 \mathrm{a}$ & 26.60 & 67.77 b \\
\hline $8-0-12$ & 250.0 & 1.59 & 0.058 & 0.5900 & $0.200 \mathrm{a}$ & 55.13 & $122.29 \mathrm{a}$ \\
\hline
\end{tabular}

\begin{tabular}{|c|c|c|c|c|c|c|c|}
\hline Fertilizer & Rate $\left(\mathrm{g} \cdot \mathrm{m}^{-2}\right)$ & $\mathbf{N}(\%)$ & P (\%) & \multicolumn{2}{|c|}{ Mahogany } & $\mathrm{Fe}(\mathrm{ppm})$ & Mn (ppm) \\
\hline Control & None & 1.51 & 0.076 & 0.645 & 0.122 & $52.95 \mathrm{bc}$ & $7.36 \mathrm{ab}$ \\
\hline $24-0-11$ & 41.7 & 1.41 & 0.061 & 0.647 & 0.141 & $68.20 \mathrm{a}$ & $8.62 \mathrm{a}$ \\
\hline $8-0-12$ & 125.0 & 1.56 & 0.079 & 0.628 & 0.105 & $42.61 \mathrm{~cd}$ & $6.01 \mathrm{bc}$ \\
\hline $8-0-12$ & 250.0 & 1.37 & 0.076 & 0.741 & 0.114 & $38.45 \mathrm{~d}$ & $4.84 \mathrm{c}$ \\
\hline$P$ value & & NS & NS & NS & NS & 0.0008 & 0.004 \\
\hline
\end{tabular}

\begin{tabular}{|c|c|c|c|c|c|c|c|}
\hline \multirow[b]{2}{*}{ Fertilizer } & \multirow[b]{2}{*}{ Rate $\left(\mathrm{g} \cdot \mathrm{m}^{-2}\right)$} & \multirow[b]{2}{*}{$\mathbf{N}(\%)$} & \multirow[b]{2}{*}{ P (\%) } & \multicolumn{2}{|c|}{ Black olive } & \multirow[b]{2}{*}{$\mathrm{Fe}(\mathrm{ppm})$} & \multirow[b]{2}{*}{ Mn (ppm) } \\
\hline & & & & $\mathrm{K}(\%)$ & $\operatorname{Mg~(\% )}$ & & \\
\hline Control & None & 1.64 & 0.169 & 0.624 & 0.315 & 34.61 & $13.64 \mathrm{~b}$ \\
\hline $24-0-11$ & 83.4 & 1.59 & 0.162 & 0.671 & 0.289 & 31.73 & $23.15 b$ \\
\hline $8-0-12$ & 125.0 & 1.61 & 0.177 & 0.669 & 0.338 & 29.94 & $24.15 \mathrm{~b}$ \\
\hline $8-0-12$ & 250.0 & 1.69 & 0.203 & 0.673 & 0.318 & 29.84 & $46.49 \mathrm{a}$ \\
\hline
\end{tabular}

\begin{tabular}{|c|c|c|c|c|c|c|c|}
\hline \multirow[b]{2}{*}{ Fertilizer } & \multirow[b]{2}{*}{ Rate $\left(\mathrm{g} \cdot \mathrm{m}^{-2}\right)$} & \multirow[b]{2}{*}{ N (\%) } & \multirow[b]{2}{*}{ P (\%) } & \multicolumn{2}{|c|}{ Beautyleaf } & \multirow[b]{2}{*}{$\mathrm{Fe}(\mathrm{ppm})$} & \multirow[b]{2}{*}{ Mn (ppm) } \\
\hline & & & & $\mathrm{K}(\%)$ & $\operatorname{Mg}(\%)$ & & \\
\hline Control & None & 1.27 & 0.070 & 0.498 & $0.123 \mathrm{~b}$ & 25.34 & $2.38 \mathrm{~d}$ \\
\hline $24-0-11$ & 41.7 & 1.21 & 0.071 & 0.497 & $0.127 \mathrm{~b}$ & 23.18 & $7.72 \mathrm{c}$ \\
\hline $24-0-11$ & 83.4 & 1.20 & 0.076 & 0.477 & $0.119 \mathrm{~b}$ & 15.86 & $12.65 \mathrm{~b}$ \\
\hline $8-0-12$ & 125.0 & 1.34 & 0.077 & 0.476 & $0.135 \mathrm{ab}$ & 16.84 & $17.14 \mathrm{a}$ \\
\hline $8-0-12$ & 250.0 & 1.31 & 0.075 & 0.492 & $0.148 \mathrm{a}$ & 19.63 & $17.77 \mathrm{a}$ \\
\hline
\end{tabular}

${ }^{2} 24-0-11$ [24N-0P-9.2K contains mostly water-soluble nitrogen $(\mathrm{N})$ and potassium $(\mathrm{K})$ plus insoluble iron (Fe) and manganese (Mn), but no magnesium (Mg)]; 8-0-12 $(8 \mathrm{~N}-0 \mathrm{P}-10 \mathrm{~K}-4 \mathrm{Mg}$ contains controlled-release $\mathrm{N}, \mathrm{K}$, and $\mathrm{Mg}$ plus water-soluble micronutrients $)$

${ }^{\mathrm{y}} \mathrm{l} \mathrm{g} \cdot \mathrm{m}^{-2}=0.2048 \mathrm{lb} / \mathrm{l}, 000 \mathrm{ft}^{2}, 1 \mathrm{ppm}=1 \mu \mathrm{g} \cdot \mathrm{g}^{-1}$.

${ }^{x}$ Mean separation by the Waller-Duncan k-ratio method $(k=100)$.

wonsignificant at $P>0.05$.

for this species, Mn concentrations in all but the high rate of 8-0-12 treatment were well below survey values (123-1148 ppm) for this element (Mills and Jones, 1996). This fertilizer treatment was also the only one that resulted in foliar Fe concentrations above the minimum published survey value of $28 \mathrm{ppm}$. All treatments resulted in $\mathrm{N}, \mathrm{P}$, and $\mathrm{K}$ concentrations below the minimum survey values ( $1.87 \%, 0.13 \%$, and $0.63 \%$, respectively).

Mahogany leaf $\mathrm{N}, \mathrm{P}, \mathrm{K}$, and $\mathrm{Mg}$ concentrations did not differ among treatments but Fe concentrations were higher for trees receiving the turf fertilizer treatments than for those receiving the palm fertilizers. The turf fertilizer contained $2 \% \mathrm{Fe}$ and $1 \%$ Mn compared with about $1.25 \%$ of both $\mathrm{Fe}$ and $\mathrm{Mn}$ for the palm fertilizer. However, because the $\mathrm{Fe}$ and $\mathrm{Mn}$ in the turf fertilizer are the mostly insoluble sucrate forms compared with the water-soluble sulfates and chelates used in the palm fertilizer, these results were not expected. Because growth rates were similar among treatments, these differences cannot be attributed to dilution effects. Because sufficiency values for foliar nutrient concentrations have not been published for this species, it was not possible to compare our results with established values.

Black olive leaves contained more Mn when fertilized with the high rate of $8-0-12$ than with any other treatment, but there were no differences in leaf concentrations of $\mathrm{N}, \mathrm{P}, \mathrm{K}, \mathrm{Mg}$, or Fe in this species. The more readily available sulfate form of $\mathrm{Mn}$ in the palm fertilizer would be expected to be more effective in increasing foliar Mn concentrations than the largely insoluble sucrate form used in the turf fertilizer (Broschat, 1991). With the exception of the high rate of 8-0-12 treatment, all other treatments resulted in leaf $\mathrm{Mn}$ concentrations well below the 40 ppm sufficiency level given by Mills and Jones (1996). This higher Mn content of the high rate of 8-0-12treated trees may have contributed to the superior overall quality in this species even though Mn deficiency 
symptoms were never observed. All treatments resulted in $\mathrm{N}$, and $\mathrm{Mg}$ concentrations above published sufficiency values $(1.6 \%$ and $0.25 \%$, respectively) for this species but no treatments produced foliar concentrations within the sufficiency ranges for $\mathrm{K}$ and $\mathrm{Fe}(0.7 \%$ and $53 \mathrm{ppm}$, respectively). Only the low rate of 24-0-11 resulted in $\mathrm{P}$ concentrations below the published sufficiency value of $0.15 \%$.

Beautyleaf leaves showed no differences in their concentrations of $\mathrm{N}$, $\mathrm{P}, \mathrm{K}$, or $\mathrm{Fe}$, but leaves of trees fertilized with either palm fertilizer rate contained significantly more Mn than other treatments and the high rate of 8-0-12-fertilized trees had more Mg than unfertilized and turf fertilizer treatments. Magnesium appeared to be important in the fertilization of this species as its ratings were highly correlated with overall plant quality in both establishment and maintenance phases. Neither sufficiency nor survey values for nutrient concentrations in this species have been published, so it was not possible to compare our data with established values.

In general, leaf concentrations of the various elements were not significantly correlated with overall tree quality (data not shown). However, leaf $\mathrm{Fe}$ concentrations in black olive were positively correlated $(r=0.664$, $P=0.0014)$ and $\mathrm{K}(r=0.451$, $P=0.05), \mathrm{P}(r=0.483, P=0.063)$, and Fe $(r=0.509, P=0.026)$ concentrations in beautyleaf were positively correlated with overall tree quality.

In summary, species differed considerably in their response to fertilizer type and application rate. With the exception of beautyleaf, fertilizer type had no effect on any species during establishment. In beautyleaf, the high rate of 8-0-12 was superior to either rate of the turf fertilizer. Either fertilizer type or rate was better than no fertilizer for all species except mahogany during establishment. Thus, less expensive turf type fertilizers would be sufficient for black olive and live oak. After establishment, live oak, black olive, and beautyleaf responded to fertilization of any kind and rate. Because rates used in this study were quite high and differences between rates were generally insignificant, it is possible that lower rates than those used in this study might prove to be adequate. Fertilizer treatment affected leaf $\mathrm{Mn}$ concentrations for all species though differently in each species. Based on this study, we do not recommend fertilization of west indian mahogany at planting or thereafter, but live oak and black olive can benefit from fertilization with either a turf fertilizer or a product formulated for palms. Beautyleaf should be fertilized only with palm-type formulations. The results from this study may not necessarily apply to other species and additional studies that include other species and lower fertilization rates are needed to more fully understand how newly planted and established trees in South Florida respond to fertilization.

\section{Literature cited}

Barker, A.V. and D.J. Pilbeam. 2007. Handbook of plant nutrition. CRC Press, Boca Raton, FL.

Broschat, T.K. 1979. Principal component analysis in horticultural research. HortScience 14:114-117.

Broschat, T.K. 1991. Effects of manganese source on manganese uptake by pygmy date palms. HortScience 26:13891391.

Broschat, T.K. and K.A. Moore. 2010. Effects of fertilization on the growth and quality of container-grown areca palm and chinese hibiscus during establishment in the landscape. HortTechnology 20:389394.

Dickey, R.D. 1977. Nutritional deficiencies of woody ornamental plants used in Florida landscapes. Univ. Florida Agr. Exspt. Sta. Bul. 791.

Gilman, E.F. 1987. Response of hibiscus to soil applied nitrogen. Proc. Florida State Hort. Soc. 100:356-357.

Gilman, E.F. 1988. Field grown hibiscus response to nitrogen rate. Proc. Florida State Hort. Soc. 101:99-101.

Gilman, E.F. and T.H. Yeager. 1990. Fertilizer type and nitrogen rate affects field-grown laurel oak and japanese ligustrum. Proc. Florida State Hort. Soc. 103:370-372.

Gilman, E.F., T.H. Yeager, and D. Kent. 2000. Fertilizer rate and type impacts magnolia and oak growth in sandy landscape soil. J. Arboric. 26:177-182.

Hach, C.C., B.K. Bowden, A.B. Koplove, and S.V. Brayton. 1987. More powerful peroxide Kjeldahl digestion method. J. Offic. Anal. Chem. 70:783-787.

Kuo, S. 1996. Phosphorus, p. 869-920. In: J.M. Bartels (ed.). Methods of soil analysis. Part 3. Chemical methods. Soil Sci. Soc. Amer., Madison, WI.

Mills, H.A. and J.B. Jones, Jr. 1996. Plant analysis handbook II. MicroMacro Publ., Athens, GA.

Scagel, C.F., G. Bi, L.H. Fuchigami, and R.P. Regan. 2008. Rate of nitrogen application during the growing season and spraying plants with urea in the autumn alters uptake of other nutrients by deciduous and evergreen container-grown Rhododendron cultivars. HortScience 43:1569-1579.

Struve, D.K. 2002. A review of shade tree nitrogen fertilization research in the United States. J. Arboric. 28:252-263. 